\title{
Relationships between temperatures and blooming dates of apple trees*
}

\section{H. G. Kronenberg}

Department of Horticulture, Agricultural University, Wageningen, Netherlands

Received 24 September; accepted 2 March 1983

Key-words: apple trees, blooming time, minimum temperatures, temperature sum

\section{Summary}

An attempt was made to find minimum temperatures during winter and spring needed for blossoming in apple trees by means of a mathematical model in which monthly different minimum temperature could be introduced. This intention did not fully succeed. There were indeed different minimum temperatures in different months. Results of the calculations with the same cultivars in two places were not entirely consistent. The model always gave February to have such high minimum temperatures $\left(6-7^{\circ} \mathrm{C}\right)$ that they prevented budding. The opinion of a level or a rising minimum temperature during the early months of the year was rejected.

\section{Introduction}

In an earlier publication (Kronenberg, 1979), the dates when the cold requirement of apple trees had been met were calculated for different places in Europe. Afterwards flower buds will start to develop if temperatures are suitable. It is generally accepted that no growth will take place below a certain minimum or base temperature.

Literature on the influence of temperature above base temperature as well as on the influence of temperature on speed of development of flower buds is scarce.

Sisler \& Overholsen (1943) analysed the relation between maximum day temperatures and dates of blossoming over 18 years. To place the different years upon a comparable basis, they considered the 'accumulated temperatures' above a day maximum of $43^{\circ} \mathrm{F}\left(6.1^{\circ} \mathrm{C}\right)$, beginning with 1 February to date of full bloom. Temperature sums ranged from $922-1148^{\circ} \mathrm{F}$ days. The use of average day temperatures (averaging 24 values of hourly temperatures) might have provided more accurate means, in their view.

Pearce \& Preston (1954) found that temperatures after 15 March had little effect

* Publication 499, Laboratorium voor Tuinbouwplantenteelt, Landbouwhogeschool, Wageningen, Netherlands. 
on date of blossoming. Abbot (1962) suggested that flower primordia reach a further stage in a mild autumn than a cold autumn. Austrey (1966) also used daily maximum temperatures over 20 years and found that for the apple cultivar McIntosh a base temperature of $6.6{ }^{\circ} \mathrm{C}$ is most likely. Winter (1974) stated that in apple after fulfilment of the cold requirement the minimum temperature was slightly above $0{ }^{\circ} \mathrm{C}$. Near blossoming time, it was $8{ }^{\circ} \mathrm{C}$; so the minimum temperature increased during the period of bud breaking. Lansberg (1974) suggested that winter rest is first followed by a period of cell division and then a period of cell elongation, with different temperature requirements.

Ashcroft et al. (1977) introduced a system of calculating 'chill units' on the base of adding up Celsius growing degree-hours $\left(\mathrm{GDH}^{\circ} \mathrm{C}\right)$ from the end of rest until full bloom of fruit trees, including the apple cultivar Delicious. In that publication, no base temperatures of apple are mentioned, but in an earlier publication Richardson et al. (1974) reported that for peaches $\mathrm{GDH}{ }^{\circ} \mathrm{C}$ were based on a minimum temperature of $4.5^{\circ} \mathrm{C}$. Supposedly Ashcroft et al. (1977) used this same temperature for Golden Delicious apples.

Conclusions from the above review are as follows.

1. The literature demonstrates a lack of knowledge of minimum or base temperature in apples.

2. If only day maximum temperatures were used, minimum values have been reported of 6.1 and $6.6^{\circ} \mathrm{C}$.

3. If average day temperatures were used, minimum temperatures were $0-8{ }^{\circ} \mathrm{C}$ and may be $4.5^{\circ} \mathrm{C}$.

4. The base temperature of an apple tree may alter during the period considered, from $0-8{ }^{\circ} \mathrm{C}$ to full bloom.

5. The use of average day temperatures is presumed to give better results than of maximum day temperatures.

6. Reaction of apple trees to temperature in spring can be influenced by temperatures during the previous summer. This means that differences in reaction to the same spring temperature may occur between years.

The availability of rather long series of blossoming dates of several apple cultivars in two places in the Netherlands allowed the calculatios reported below.

\section{Available data}

At the Laboratory of Horticulture in Wageningen, dates of apple blossoming have been recorded over the period 1927-1947 (Kramer, 1949). For these data, a tree was considered blossoming when $20 \%$ of its flowers were open.

At the Research Station for Fruit Growing in Goes (province of Zeeland), systematic records of blossoming dates started in 1971. Table 1 gives a survey of the records used (unpublished).

For this paper, apple cultivars were selected that could be expected to show differences in reaction to temperature. White Transparent is a very early cultivar, whereas Schone van Boskoop is a rather late one. For both cultivars, Wageningen and Goes have recorded blossoming dates. So it was possible to compare the series. 
Table 1. Records of apple blossoming used in this paper and survey of all calculations made.

\begin{tabular}{|c|c|c|c|c|}
\hline Cultivar & Place & Years & $\begin{array}{l}\text { Number } \\
\text { of years }\end{array}$ & $\begin{array}{l}\text { Number of } \\
\text { combinations } \\
\text { investigated }\end{array}$ \\
\hline Schone van Boskoop & Wageningen & $\begin{array}{l}1927-1947 \\
\text { (1944 and } 1945 \text { missing) }\end{array}$ & 19 & $176^{*}$ \\
\hline White Transparent & Wageningen & $\begin{array}{l}1927-1946 \\
\text { (1944 and } 1945 \text { missing) }\end{array}$ & 18 & $12^{*}$ \\
\hline Cox's Orange Pippin & Goes & $1971-1980$ & 10 & 409 \\
\hline Golden Delicious & Goes & $1971-1980$ & 10 & 399 \\
\hline Granny Smith & Goes & $1971-1975$ & 5 & 440 \\
\hline James Grieve & Goes & $1971-1980$ & 10 & 430 \\
\hline Jonathan & Goes & $1971-1980$ & 10 & 387 \\
\hline Lombarts Calville & Goes & $1974-1980$ & 7 & 430 \\
\hline Schone van Boskoop & Goes & $1971-1980$ & 10 & 386 \\
\hline White Transparent & Goes & $1971-1976$ & 6 & 480 \\
\hline
\end{tabular}

* A pilot study had already given some evidence (White Transparent 400 combinations, Schone van Boskoop 8).

Unfortunately White Transparent data from Goes covered only 6 years. Schone van Boskoop is still a major cultivar. So are Cox's Orange Pippin, Golden Delicious and James Grieve. Granny Smith is a very late cultivar and, like Jonathan, not very well adapted to the Dutch climate. Lombarts Calville has recently been planted more and is a promising cultivar. Temperature records of two meteorological stations were used (Koninklijk Nederlands Meteorologisch Instituut, 1972-1980). The main meteorological station in the Netherlands is situated at De Bilt, $40 \mathrm{~km}$ west of Wageningen. For 1945, no records are available. Temperature differences between De Bilt and Wageningen are only small, if any. So records for De Bilt were associated with blossoming dates in Wageningen. The dates in Goes were associated with data from the meteorological station at Vlissingen, $20 \mathrm{~km}$ west of Goes.

As average day temperatures were presumed to give better results than maximum day temperatures, average day temperatures composed of 24 hourly averages were used for calculation.

The mean date when the cold requirements had been met was 22 January (Kronenberg, 1979) for De Bilt. For Zeebrugge ( $20 \mathrm{~km}$ south of Vlissingen), the same date holds true. Therefore 22 January was used for Vlissingen too. As information on the minimum temperature in the literature is contradictory, a calculation model was designed which allowed investigation of influences of different minimum temperatures in January, February, March, April and May.

\section{Model}

The literature survey gives reasons for the assumption that date of blossoming is determined by mean day temperatures. Each day (after 22 January) contributes a quantity $\tau_{\mathrm{j}}=t_{j}-b$ to the sum of temperatures, where $t_{j}$ stands for the mean day- 
temperature and $b$ for the base temperature. A day temperature below $b$ does not contribute. As soon as the sum of day temperatures in a year exceeds a quantity $T$ (the needed sum of temperatures), the tree is expected to blossom. In equation,

$$
T+\varepsilon_{i}=\sum_{j=1}^{J_{i}} \tau_{i j}
$$

where:

$$
\begin{aligned}
& T=\text { needed sum } \\
& \tau_{i j}= \begin{cases}t_{i j}-b & t_{i j} \geqslant b \\
0 & t_{i j}<b\end{cases} \\
& \tau_{\mathrm{ij}} \quad=\text { mean day-temperature, year } i, \text { day } j \text { (counted from 22 Jan.) } \\
& b \quad=\text { base temperature } \\
& J_{i} \quad \text { = day of blossoming (counted from 22 Jan.), year } i \text { (stochastic variable) } \\
& \varepsilon_{\mathrm{i}} \quad \text { = random component (due to other influences). }
\end{aligned}
$$

The parameters we wished to estimate were the base temperature $b$ and the needed sum of temperatures $T$; the date of blossoming $\left(J_{i}\right)$ was observed (dependent, explained variable), the explanatory or independent variables were the mean day temperatures $\left(t_{i j}\right)$.

The model became more complicated when we permitted different base-temperatures; we assumed the base-temperature constant for a month. For simplicity below, only one temperature $(b)$ was used. It is easy to generalize the story to five temperatures $\left(b_{1}, b_{2}, b_{3}, b_{4}\right.$ and $\left.b_{5}\right)$.

Given the model, the problem is to find the best estimates of parameters. Therefore we need a criterion to measure the goodness of fit of an estimate. Define:

$$
\hat{J}_{i}=\min _{k}\left\{J_{k}: T \leqslant \sum_{j=1}^{J k} \tau_{i j}\right\} \begin{aligned}
& (\text { expected day of blossoming, } \\
& \text { given } b \text { and } T) .
\end{aligned}
$$

in which $k$ is the number of days (counted from 22 January)

$$
\begin{aligned}
& d_{i}=J_{i}-\hat{J}_{i} \\
& D^{2}=\sum_{i=1}^{n} d_{i}^{2} n=\text { number of years } \\
& \bar{D}^{2}=\frac{1}{n} D^{2}=\frac{1}{n} \sum_{i=1}^{n}\left(J_{i}-\hat{J}_{i}\right)^{2}
\end{aligned}
$$

So $d_{i}$ is the difference between the observed day of blossoming and the expected day of blossoming, given $b$ and $T$. $D^{2}$ can be used to measure the goodness of fit of estimates (the smaller $D^{2}$, the better the estimates).

Another criterion is: 


$$
A^{2}=\sum_{i=1}^{n} a_{i}^{2}
$$

where

$$
\begin{aligned}
a_{i} & =T_{i}-T \\
T_{i} & =\sum_{j=1}^{J_{i}} \tau_{i j} \\
\tau_{i j} & = \begin{cases}t_{i j}-b & t_{i j} \geqslant b \\
0 & t_{i j}<b\end{cases}
\end{aligned}
$$

So $a_{i}$ is the difference between the observed sum of temperatures, given $b$, and the (theoretically) needed sum of temperatures. Criterion $A^{2}$, however, is unsatisfactory, because for $b$ great enough (e.g. for $50^{\circ} \mathrm{C}$ ) and $T=0, A=0$.

The problem is now to find that combination of base temperatures and needed sum, $T$, that minimizes the value of $D^{2}$. Because we did not know an algorithm to solve this, we used the method of trial and error. The procedure was as follows.

1. Take a combination of base temperatures.

2. Compute $T_{i}(i=1,2, \ldots n)$ and the mean

$$
\bar{T} .=\frac{1}{n} \sum_{i=1}^{n} T_{i}^{2}
$$

3. For several values of $T$ near $\bar{T}$ (e.g. $T=\bar{T} \pm 20, \pm 15, \pm 10, \pm 5,+0$ ) compute $D^{2}$.

This was done for several combinations of base temperatures. Table 1 gives a survey of all calculations made.

The number of investigated combinations (e.g. Jan 1, Feb 6, Mar 2, Apr 2, May 3) was not very informative. Trial and error showed that certain combinations gave lower values for $D^{2}$ than others. To be sure that it was not likely that other adjoining combinations would give lower $D^{2}$, such combinations were tried too. So with less than $0.48-0.76 \%$ of all possible combinations tried out, it seems certain that the lowest $D^{2}$ was found.

\section{Results}

Of the two criteria, only $D$ is used here. All the results of the calculations were arranged according the value of $D^{2}$. The 25 best (out of 176) results for Schone van Boskoop, both in Wageningen and in Goes, are given in Table 2, from which the foilowing conclusions can be drawn.

1. Results of the calculations for Wageningen and Goes differ, especially in March. In Wageningen, March had in all 25 proposed minimum temperatures a low value $\left(1-3^{\circ} \mathrm{C}\right)$; in Goes this value was always high $\left(6-8^{\circ} \mathrm{C}\right)$. 
Table 2. $D^{2}, \bar{D}^{2}$, temperature sum $\left(T\right.$, in day $\left.{ }^{\circ} \mathrm{C}\right)$ and minimum temperatures $\left({ }^{\circ} \mathrm{C}\right)$ of Schone van Boskoop.

\begin{tabular}{|c|c|c|c|c|c|c|c|c|c|c|c|c|c|c|c|}
\hline \multicolumn{8}{|c|}{ Wageningen (19 years) } & \multicolumn{8}{|c|}{ Goes (10 years) } \\
\hline \multirow[t]{2}{*}{$D^{2}$} & \multirow[t]{2}{*}{$\bar{D}^{2}$} & \multirow[t]{2}{*}{$T$} & \multicolumn{5}{|c|}{ Minimum temperatures } & \multirow[t]{2}{*}{$D^{2}$} & \multirow[t]{2}{*}{$\bar{D}^{2}$} & \multirow[t]{2}{*}{$T$} & \multicolumn{5}{|c|}{ Minimum temperatures } \\
\hline & & & Jan & Feb & Mar & Apr & May & & & & Jan & Feb & Mar & Apr & May \\
\hline 26 & 1.4 & 363 & 1 & 6 & 2 & 3 & 3 & 42 & 4.2 & 171 & 4 & 6 & 7 & 4 & 3 \\
\hline 32 & 1.7 & 360 & 1 & 7 & 2 & 3 & 3 & 42 & 4.2 & 166 & 4 & 6 & 7 & 4 & 4 \\
\hline 33 & 1.7 & 332 & 1 & 7 & 3 & 3 & 3 & 44 & 4.4 & 172 & 3 & 6 & 7 & 4 & 4 \\
\hline 34 & 1.8 & 419 & 1 & 7 & 1 & 2 & 3 & 44 & 4.4 & 134 & 5 & 6 & 7 & 5 & 4 \\
\hline 34 & 1.8 & 335 & 1 & 6 & 3 & 3 & 3 & 45 & 4.5 & 160 & 4 & 6 & 6 & 5 & 2 \\
\hline 35 & 1.8 & 380 & 1 & 7 & 1 & 3 & 3 & 45 & 4.5 & 139 & 4 & 6 & 7 & 5 & 4 \\
\hline 35 & 1.8 & 449 & 1 & 7 & 1 & 1 & 3 & 46 & 4.6 & 154 & 2 & 7 & 7 & 5 & 2 \\
\hline 35 & 1.8 & 423 & 1 & 6 & 1 & 2 & 3 & 46 & 4.6 & 153 & 2 & 7 & 8 & 5 & 2 \\
\hline 35 & 1.8 & 389 & 1 & 6 & 1 & 3 & 3 & 47 & 4.7 & 149 & 4 & 6 & 7 & 5 & 2 \\
\hline 36 & 1.9 & 349 & 1 & 7 & 2 & 3 & 4 & 47 & 4.7 & 163 & 4 & 7 & 7 & 4 & 3 \\
\hline 36 & 1.9 & 358 & 2 & 6 & 2 & 3 & 3 & 47 & 4.7 & 163 & 4 & 7 & 7 & 4 & 4 \\
\hline 37 & 1.9 & 442 & 1 & 6 & 1 & 1 & 3 & 48 & 4.8 & 147 & 2 & 6 & 8 & 5 & 4 \\
\hline 38 & 2.0 & 423 & 1 & 6 & 1 & 2 & 2 & 48 & 4.8 & 167 & 3 & 6 & 7 & 4 & 5 \\
\hline 38 & 2.0 & 354 & 2 & 7 & 2 & 3 & 3 & 49 & 4.9 & 143 & 2 & 7 & 8 & 5 & 4 \\
\hline 38 & 2.0 & 353 & 2 & 8 & 2 & 3 & 3 & 49 & 4.9 & 212 & 3 & 7 & 6 & 3 & 3 \\
\hline 39 & 2.1 & 397 & 1 & 6 & 2 & 2 & 2 & 49 & 4.9 & 147 & 3 & 7 & 7 & 5 & 2 \\
\hline 39 & 2.1 & 457 & 1 & 6 & 1 & 1 & 2 & 50 & 5.0 & 175 & 2 & 6 & 7 & 4 & 4 \\
\hline 39 & 2.1 & 423 & 2 & 6 & 1 & 2 & 2 & 50 & 5.0 & 181 & 2 & 7 & 7 & 4 & 2 \\
\hline 39 & 2.1 & 378 & 2 & 8 & 1 & 3 & 3 & 50 & 5.0 & 259 & 3 & 5 & 6 & 2 & 2 \\
\hline 40 & 2.1 & 394 & 1 & 7 & 2 & 2 & 2 & 50 & 5.0 & 161 & 5 & 6 & 7 & 4 & 4 \\
\hline 40 & 2.1 & 454 & 1 & 7 & 1 & 1 & 2 & 51 & 5.1 & 200 & 3 & 6 & 7 & 3 & 3 \\
\hline 40 & 2.1 & 388 & 2 & 6 & 1 & 1 & 3 & 51 & 5.1 & 191 & 4 & 7 & 7 & 3 & 3 \\
\hline 42 & 2.2 & 425 & 1 & 7 & 1 & 2 & 2 & 52 & 5.2 & 173 & 4 & 7 & 6 & 4 & 4 \\
\hline 42 & 2.2 & 452 & 2 & 6 & 1 & 1 & 2 & 53 & 5.3 & 260 & 1 & 6 & 6 & 2 & 2 \\
\hline 42 & 2.2 & 407 & 2 & 6 & 1 & 2 & 3 & 53 & 5.3 & 252 & 2 & 6 & 6 & 2 & 2 \\
\hline
\end{tabular}

2. $D^{2}$ was lower in Wageningen than in Goes, which means that the suggested Wageningen minimum temperatures are more likely.

3. Differences between the various values of $D$ were very small: the first row of suggested minimum temperatures and the second (or third and so on) had nearly the same probability.

4. The value of $\bar{D}$ was slightly more than 1 day for Wageningen and about 2 days for Goes. It is a well known fact, however, that the human estimates of $20 \%$ blossoming may be one day wrong. This makes the Wageningen minimum temperatures indeed acceptable.

To make a survey of all calculations feasible, a shorter system of reporting than Table 2 was needed. The first 5 lines of Table 2 (Wageningen) can be summarized as follows: 


\begin{tabular}{llllllll}
$D^{2}$ & $\bar{D}^{2}$ & $T$ & \multicolumn{9}{c}{ Minimum temperatures } \\
& & & Jan & Feb & Mar & Apr & May \\
26-34 & $1.4-1.8$ & $332-419$ & 1 & $6-7$ & $1-3$ & $2-3$ & 3
\end{tabular}

In this way, Table 3 was composed.

Conclusions from Table 3 were as follows.

1. Results of calculations for Wageningen and Goes led to different series of minimum temperatures.

2. That the results of the calculations differ between Wageningen and Goes held true for all cultivars investigated. It seems that these differences must be ascribed to a different behaviour of the trees in the two places.

3. Differences in reaction to temperature between the cultivars were small. So apple cultivars always flower in about the same sequence (a well known fact).

Special calculations were made to find out if a level minimum temperature (Sisler \& Overholsen, 1943) or a rising minimum temperature (Winter, 1974, p. 46) were acceptable suggestions. Table 4 gives the results and is complete for level temperatures ( 9 temperatures were always calculated), but quite incomplete for rising temperatures. All calculations were directed to finding low $D^{2}$ and therefore only some sequences with rising temperatures were tried. It is very likely that, with rising minimum temperatures, one can find better combinations with lower $D^{2}$ than given in the second half of Table 4. However, neither Sisler \& Overholsen's nor Winter's model was satisfactory (Table 4). Values of Table 3 are much better.

\section{Discussion and conclusions}

As expected prediction of blossoming dates of apple trees with a mathematical model based on a fixed temperature sum and accepting certain minimum temperatures per month was not entirely successful. It is a well known phenomenon that a number of hot days starts processes, which continue in the plant during the following days despite any lower temperatures then prevailing. High minimum temperatures in February and March point into this direction.

Table 3. $D^{2}, \bar{D}^{2}$, temperature sums $\left(\right.$ day $\left.{ }^{\circ} \mathrm{C}\right)$ and minimum temperatures $\left({ }^{\circ} \mathrm{C}\right)$ of 8 cultivars investigated.

\begin{tabular}{|c|c|c|c|c|c|c|c|c|c|}
\hline \multirow[t]{2}{*}{ Cultivar } & \multirow[t]{2}{*}{ Place } & \multirow[t]{2}{*}{$D^{2}$} & \multirow[t]{2}{*}{$\overline{\bar{D}^{2}}$} & \multirow[t]{2}{*}{$T$} & \multicolumn{5}{|c|}{ Minimum temperatures } \\
\hline & & & & & Jan & Feb & Mar & Apr & May \\
\hline Schone van Boskoop & Wageningen (19 years) & $26-34$ & $1.4-1.8$ & $332-419$ & 1 & $6-7$ & $1-3$ & $2-3$ & 3 \\
\hline White Transparent & Wageningen ( 18 years) & $24-39$ & $1.3-2.2$ & $264-383$ & 2 & 7 & $2-4$ & $2-4$ & $2-4$ \\
\hline Cox's Orange Pippin & Goes ( 10 years) & $37-47$ & $3.7-4.7$ & $149-248$ & $3-5$ & $5-6$ & $6-7$ & $3-6$ & $3-4$ \\
\hline Golden Delicious & Goes (10 years) & $52-57$ & $5.2-5.7$ & $161-202$ & $4-7$ & 6 & 7 & $4-5$ & $3-4$ \\
\hline Granny Smith & Goes (5 years) & $26-35$ & $5.2-7.0$ & $128-177$ & $2-5$ & $6-7$ & 7 & $5-6$ & $4-5$ \\
\hline James Grieve & Goes (10 years) & $55-60$ & $5.5-6.0$ & $142-211$ & $5-7$ & $6-7$ & $6-7$ & $3-5$ & $4-5$ \\
\hline Jonathan & Goes ( 10 years) & $38-47$ & $3.8-4.7$ & $132-177$ & $2-5$ & $6-7$ & $7-8$ & $5-6$ & $4-5$ \\
\hline Lombarts Calville & Goes (7 years) & $20-26$ & $2.9-3.7$ & $208-255$ & $2-6$ & $5-7$ & $7-8$ & $2-3$ & $2-3$ \\
\hline Schone van Boskoop & Goes (10 years) & $42-45$ & $4.2-4.5$ & $134-172$ & $3-5$ & 6 & 7 & $4-5$ & $2-4$ \\
\hline White Transparent & Goes (6 years) & $22-29$ & $3.7-4.8$ & $156-202$ & $2-4$ & 6 & $6-7$ & $4-6$ & 4.5 \\
\hline
\end{tabular}


Table 4. Lowest $D^{2}$ with level or rising minimum temperatures $\left({ }^{\circ} \mathrm{C}\right)$ for all cultivars investigated.

\begin{tabular}{|c|c|c|c|c|c|c|c|c|c|}
\hline \multirow[t]{3}{*}{ Cultivar } & \multirow[t]{3}{*}{ Place } & \multicolumn{2}{|c|}{$\begin{array}{l}\text { Level minimum } \\
\text { temperature }\end{array}$} & \multicolumn{6}{|c|}{$\begin{array}{l}\text { Rising minimum } \\
\text { temperature }\end{array}$} \\
\hline & & \multirow{2}{*}{\multicolumn{2}{|c|}{$\begin{array}{l}\text { lowest temperature } \\
D^{2} \quad \text { Jan-May }\end{array}$}} & \multirow{2}{*}{$\begin{array}{l}\text { lowest } \\
D^{2}\end{array}$} & \multicolumn{5}{|c|}{ temperatures } \\
\hline & & & & & Jan & Feb & $\mathrm{Ma}$ & I Ap & r May \\
\hline Schone van Boskoop & Wageningen (19 years) & 73 & 2 & 86 & 1 & 4 & 4 & 4 & 4 \\
\hline White Transparent & Wageningen (18 years) & 317 & 4 & 326 & 3 & 4 & 4 & 4 & 4 \\
\hline Cox's Orange Pippin & Goes ( 10 years) & 77 & 5 & 131 & 3 & 4 & 4 & 4 & 4 \\
\hline Golden Delicious & Goes (10 years) & 155 & 7 & 178 & 2 & 4 & 4 & 7 & 9 \\
\hline Granny Smith & Goes ( 5 years $)$ & 79 & 8 & 74 & 6 & 7 & 7 & 7 & 7 \\
\hline James Grieve & Goes (10 years) & 108 & 7 & 147 & 6 & 7 & 7 & 7 & 7 \\
\hline Jonathan & Goes (10 years) & 110 & 7 & 191 & 1 & 3 & 5 & 7 & 9 \\
\hline Lombarts Calville & Goes ( 7 years) & 106 & 7 & 197 & 6 & 7 & 8 & 8 & 8 \\
\hline Schone van Boskoop & Goes (10 years) & 115 & 5 & 46 & 3 & 4 & 4 & 4 & 4 \\
\hline White Transparent & Goes (10 years) & 42 & 7 & 71 & 3 & 3 & 4 & 4 & 4 \\
\hline
\end{tabular}

Situations as described above will happen somewhat later in winter and lower minimum temperatures in April and May indicate that all kinds of processes in the plant go on, despite lower prevailing temperatures. As another reason for failure, one can suggest that not air temperatures, recorded in a meteorological cabin, but actual 'bud temperatures' should be used. During sunny weather, bud temperatures will be higher than air temperature; during clear nights much lower.

Differences between the behaviour of trees at Wageningen and Goes may be partly explained by a windier and sunnier climate in Goes. Only very complicated mathematical models could take full account of all these factors. A final remark is that influences of soil temperatures, influencing the water supply of a tree, may play a part.

In spite of these limitations, the model has given new information.

1. There are several minimum temperatures during flower development in apple trees. All 8 cultivars investigated showed this phenomenon.

2. High minimum temperatures in February (and March) seem useful to prevent too early development of the buds. It is, however, possible that the very low January values found in Wageningen indicate that some cell division processes not completed the year before must take place first (as suggested by Lansberg, 1974). In the somewhat milder Goes climate, the same processes may have taken place in autumn and a higher minimum temperature blockade is needed (and found)!

3. A more speculative remark is that low values of $\bar{D}^{2}$ mean that the model fits rather well or that the reactions of the tree follow a certain rule every year. So cultivars with low $\bar{D}^{2}$ are better adapted to winter and spring climate than others. And though reactions at different places were not uniform, adaptation to a certain place can be better than to others.

The apple cultivar with the lowest $\bar{D}^{2}$ (Goes) is Lombarts Calville, which was bred and selected in Zundert (1906) only $40 \mathrm{~km}$ from Goes. So good adaptation to environmental conditions may be supposed. The second best is Cox's Orange Pip- 
pin with 3.7-4.7. This cultivar crops well only in places with a high humidity. This holds for Goes.

The cultivar with the highest $\bar{D}^{2}$ at Goes was Granny Smith with 5.2-7.0. Granny Smith originated from a chance seedling from Australia and it is a well known fact that it adapts itself very badly to the climate of the Netherlands.

\section{Acknowledgement}

P. H. van Ewijk designed the mathematical model and wrote that part of this paper. P. H. van Ewijk and R. Buiskool did all the calculations. Both are thanked for their invaluable help.

\section{References}

Abbott, D. L., 1962. The effect of four controlled winter temperatures on the flowering and fruiting of apple. J. hort. Sci. 37: 272-284.

Ashcroft, G. L., E. A. Richardson \& S. D. Seeley, 1977. A statistical method of determining chill unit and growing degree hour requirements for decidious fruit trees. Hort. Sci. 12(4): 347-348.

Austrey, T. H. 1966. Prediction of full blossom date for apple, pear, cherry, peach and apricot from air temperature data. Proc. Am. Soc. hort. Sci. 88: 57-65.

Koninklijk Nederlands Meteorologisch Instituut, 1927-1980. Jaarboek Koninklijk Nederlands Meteorologisch Instituut, A. Meteorologie.

Kramer, C., 1949. Onderzoek naar de bloei- en rijpheidsstadia van hard fruit. Fruitteelt (6): 104-106.

Kronenberg, H. G., 1979. Apple growing potentials in Europe. I. The fulfilment of the cold requirement of the apple tree. Neth. J. agric. Sci. 27: 131-135.

Lansberg, J. J., 1974. Apple fruit bud development and growth: analysis and an empirical model. Annls. Bot. 38: 1013-1023.

Pearce, S. C. \& A. P. Preston, 1954. Forecasting the time of blossoming in apple trees from temperature records. Rep. E. Malling Res. Stn 1953: 133-137.

Richardson, E. A., S. D. Seeley \& D. R. Walker, 1975. Pheno climatography of spring peach and development. Hort. Sci. 10(3): 236-237.

Sisler, G. P. \& E. L. Overholsen, 1943. Influences of climatic conditions on date of full bloom of Delicious apples in the Wenachee Valley. Proc. Am. Soc. hort. Sci. 43: 29-34.

Winter, F., 1981. Lucas' Anleitung zum Obstbau, Eugen Ulmer, Stuttgart, 30. Auflage: 45-46. 